\title{
CITY-MAKING THROUGH URBAN GARDENING: PUBLIC SPACE AND CIVIC ENGAGEMENT IN ZAGREB
}

Original scientific paper Received: 11. 3. 2018 Accepted: 24. 4. 2018. DOI: $10.15176 /$ vol55no109 UDK 39:316(497.5Zagreb) $711.4(497.521 .2)$

\author{
VALENTINA GULIN ZRNIĆ \\ Institute of Ethnology and Folklore Research, Zagreb
}

TIHANA RUBIĆ

Department of Ethnology and Cultural Anthropology, Faculty of Humanities and Social Sciences, University of Zagreb

\begin{abstract}
This paper focuses on four examples of Zagreb urban gardening communities: their actors, their structures, and the aims of the established gardens. The article begins by introducing the practice and perception of the illegal ("wild") gardens that have existed in Zagreb on vacant and derelict plots for decades. A discussion of the changing contexts of urban gardening within the last few years follows. Further ethnographic examples of new, alternative, and hybrid gardens indicate the variety of organizational methods and actors involved, types of communality and solidarity, and the negotiation and debate regarding discursive, structural, and governance issues. The analysis aims to examine the heterogeneity of gardening communities in Zagreb and to illuminate the dynamics (changes and modifications) of various relationships that are constituent to the phenomenon. The article concludes by considering the politics of space, particularly the transformation of urban public spaces, and the potential of gardening initiatives in the sphere of contemporary urban governance strategies.
\end{abstract}

Keywords: urban gardening, transition movement, politics of public space, community building, post-socialist city, Zagreb

\section{INTRODUCTION}

Community garden literature is a growing field, especially since the 2000s. It marks new grassroots sensibilities regarding cities and the environment, as well as an awareness of and engagement in alternatives to the dominant (neoliberal) capitalist world framework. The studies address the contribution of community gardens and gardening to food 
security and environmental justice; greening the city; enhancing health and recreation; raising neighbourhood safety; promoting and building social networks, inclusion, solidarity, and cohesion (Armstrong 2000; Glover 2004; Gootlieb and Joshi 2010; Kingsley and Townsend 2006; Firth et al. 2011). The community building process - which goes hand in hand with gardening in many urban initiatives - has further empowered urbanites to negotiate other contested urban issues (such as the shrinking of public spaces or neoliberal urban governance), thus fostering gardens as sites of collective social action and political activism (Krasny 2012; Nettle 2014).

In Zagreb, community gardens became a publicly debated issue in 2012 provoked by the destruction of illegal gardens in the Zagreb housing estate of Travno. Before then, urban gardening had not garnered much of academic or public attention. It was regarded as a trivial and marginal practice of interest to sociological theories and debates on the development of the (socialist) city. Still, from the ethnological and cultural-anthropological perspective of everyday life, it was noted by Dunja Rihtman-Auguštin as a complex phenomenon and interpreted within the triangle of "alternative urbanization", "appropriation of city", and "everyday creativity" (Rihtman-Auguštin 1988: 96-101). Two decades later, the description of illegal gardens (colloquially known in Croatian as "wild" gardens - "divlji" vrtovi) and the perception of gardeners has been included in urban anthropological research on local urban identities (Gulin Zrnić 2009). By 2012, urban gardens were briefly mentioned in sociological literature as a part of a sustainable city agenda (Butorac and Šimleša 2007) and as an example of a discrepancy between planned and real use of space (Stojan and Čaldarović 2006).

Both academic and general interest in urban gardening in Zagreb and Croatia have risen since 2012. A series of public debates and lectures has taken place, and a number of civic associations and initiatives have been created, all focused on promoting and organizing urban gardening and shared ecological topics. In many Croatian cities, urban gardening has become organized through municipal plans or civil initiatives (Zagreb, Pula, Varaždin, Velika Gorica, Sisak, Osijek, Rijeka, Karlovac, Virovitica, Koprivnica, Belišće, Ivanić-Grad etc.). Gardens germinated in various forms in subsequent years: as art gardens in urban public spaces (ArtEnergy, Zagreb, 2013); therapeutic gardens at hospitals (University Hospital Centre, Zagreb, 2012); school and university gardens (many primary schools, Borongaj University Campus; Pupils' boarding home, Rijeka, etc.). Scientists, gardeners, activists, and artists have produced papers analysing, interpreting, or commenting on the recent social, ecological, and political phenomenon of "the gardens of our city" (Rubić and Gulin Zrnić 2015). Recent articles study the perceptions, meanings, investments, and perspective of current gardening practices (Biti and Blagaić Bergman 2014; Slavuj Borčić et al. 2015; Jambrešić Kirin 2015; Ursić et al. 2018), civil participation and the organization of gardens (Toš 2015; Dobrić 2015; Radovanović 2015), community orchards (Pavlović Lučić 2015), the potential of therapeutic gardens (Dujmović 2016), school gardens (Trajkov 2015), as well as educational and multisensory gardens (Novak 2015; Butorac 2015), gardens in artistic practice (Marjanić 2015), and the issue of food sovereignty (Janovski 
2015; Orlić 2014; Komazlić 2015). Some research also deals with urban and school gardening from a historical perspective (Kolar-Dimitrijević 2014; Glasnova 2014; Grbić Jakopović 2015). The proliferation of literature on urban gardening signals that the topic is both complex and contested in multiple perspectives.

The authors of this research have participated in public discussions, research, and civic activism in various ways over the years. In the 2000s, Valentina Gulin Zrnić carried out research on urban gardens through the perspective of social practices and local urban identities in Zagreb's housing estates (Travno, Trnsko) built during socialism (2009). In 2013-2014, she undertook additional research on urban gardening (in the Dugave, Travno, Sopot, and Siget housing estates) with a particular interest in the changed circumstances and discourses over gardening, as well as in the new organization of Zagreb city-run gardens. The research was part of her engagement in this pertinent urban issue, as well as a part of artistic collaborations that had been developed as an active and reflective reaction towards the current state of urban gardening in Zagreb. This research and artistic collaboration is realised as "Garden Circles" project (Krugovi u vrtu, 2013) by Tonka Maleković, which includes a series of artistic performances in gardens, interviews with gardeners, and documentation of the state of the former garden location in Travno a year after its destruction ("garden archaeology"), indicating the persistence of vegetable and herb seeds now growing in the park. 'Another research-artistic collaboration is "The Siget Modern" by French artist Jean Michel Bruyère in 2014, with the gardens of New Zagreb as the focus of a debate on ecology, capitalism, and everyday life in the modern city and the intent to organize a "centre of free common cultures" in a derelict storefront in the Siget housing estate. ${ }^{2}$

Tihana Rubić, as a former resident of Travno housing estate, was critically oriented towards the decision of the municipal authorities to remove the "wild" gardens in 2012. She participated in various projects and civic actions in Zagreb that served to establish Zagreb's first community garden. She was an active member of the civic initiative Parkticipacija from its beginnings in 2012, and collaborated with various civic initiatives/associations that promoted sustainability and solidarity in the urban public space (such as Kontraakcija, Zelena akcija, Hrana, a ne oružje, BADco. and 1postozagrad). She has participated in a series of art, guerrilla, and public gardening activities in Zagreb from 2012 - 2015, including the "ArtEnergy" project in 2013 (in collaboration with the Croatian Association of Artists, Zagreb). ${ }^{3}$ At the Faculty of Humanities and Social Sciences in Zagreb, she organized and

1 This project was realized as part of the "Essbare Stadt" (Edible City) Project by Goethe-Institut Kroatien, 2013. On the "Garden Circles" project, see Maleković and Gulin Zrnić (2015).

2 The collaboration was realized as part of EUROKAZ projects: the preliminary (research) phase was undertaken in 2014 and presented at the Museum of Contemporary Art in Zagreb in 2015 http://www. eurokaz.hr/v3/projects/siget-modern (accessed April 2018). The artist wrote an accompanying text ("The Siget Modern. Swap center of free common cultures") which has been translated into Croatian (manuscript). Neither the publishing nor the project have been fully realised due to financial reasons.

3 The "ArtEnergy" project promoted sustainability in public space and everyday life, merging art, new technologies, and music. The project was designed to highlight and inspire the importance of environmen- 
coordinated an initiative to establish an academic garden (2013), coordinated a written study for the academic garden and served as co-organizer and promoter of a series of urban gardening forums, round tables, workshops, and civic actions. She has participated in civic initiatives to preserve green public spaces (parks) in two neighbourhoods - Savica (2013) and Kajzerica (2015).

From 2014 onward, the authors' research, fieldwork, and engagement with urban gardening themes, and with various civil initiatives on a general level, have become framed within an academic project on urban transformations of Zagreb - "City-making: space, culture, and identity". ${ }^{4}$ An edited volume on urban gardening has been published (Rubić and Gulin Zrnić 2015, 2016) as a collection of various texts (academic papers, essays, blog texts, garden diaries, reviews, etc.) that document, study, and reflect on the current state of urban gardening, public spaces, civil activism, and sustainable city politics in Zagreb and Croatia in general. The material has also been presented and discussed at academic conferences, and the "garden book" prompted meetings with various groups of gardeners. ${ }^{5}$ The long-term fieldwork and engagement of both authors produced the material for this text.

This paper focuses on four examples of urban gardening communities: their actors, their structures, and the aims of the established gardens. The article begins by introducing the practice and perception of the illegal ("wild") gardens that have existed in Zagreb on vacant and derelict plots for decades. A discussion of the changing contexts of urban gardening within the last few years follows. Three further ethnographic examples of new, alternative, and hybrid gardens indicate the variety of organizational methods and actors involved, types of communality and solidarity, and the negotiation and debate regarding discursive, structural, and governance issues. The analysis aims to examine the heterogeneity of gardening communities in Zagreb and to illuminate the dynamics (changes and modifications) of various relationships that are constituent to the phenomenon. The article concludes by considering the politics of space, particularly the transformation of urban public spaces, and the potential of gardening initiatives in the sphere of contemporary urban governance strategies.

tal conservation, waste material utilisation, and land-based responsibility. The project (urban garden) was displayed and organised in front of the Croatian Association of Artists' building, in the city centre. See more at http://www.hdlu.hr/2013/06/artenergy/ (accessed April 2018).

${ }^{4}$ Project website: www.citymaking.eu.

${ }^{5}$ The research on urban gardens in Zagreb has been presented at the "Cultures of Crisis" conference, InASEA, Istanbul 2014; "Urban gardens and architecture" (Faculty of Architecture), Zagreb, 2017; "Citymaking: space, culture and identity”, Zagreb 2018. Several articles have been published as a thematic section titled "Urban gardening" (Urbano vrtlarenje) in Zarez - Dvotjednik za kulturu i društvena zbivanja magazine (Rubić and Šimpraga 2012), which has been distributed to members of the municipality. The book draft has been presented together with a talk to gardeners in Pula (2013), and after the book was published, in Rijeka (2016), in the neighbourhood of Travno in Zagreb (2017), and with school gardeners (Davorin Trstenjak Primary School, Trnje, Zagreb) (2017). 


\section{ILLEGAL ("WILD") GARDENS IN SOCIALIST AND POST-SOCIALIST ZAGREB}

Formerly illegal gardens - known as "wild" gardens by locals - have been spreading for decades on urban (municipal) abandoned and vacant plots. It is interesting to note a brief comment on gardens included in the Zagreb Master Plan of 1971. In defining types of "public green spaces" (city parks, housing estate parks, protective green belts, etc.) there is a note that "small gardens, intended for the recreation of citizens who live in apartment buildings, will not be provided because the possible adequate locations for gardens would be at too great a distance" (Generalni urbanistički plan Zagreba 1971: 58). An interview with a professional who worked in the Zagreb Urban Planning Bureau (Urbanistički zavod grada Zagreba) and participated in the preparation of the green spaces section of the 1971 Master Plan indicates that urban gardens were actually discussed. ${ }^{6}$ Although the idea was not realized, it left its trace within the Master Plan in a peculiar explanation of green public space that is not planned or provided. Several current employees of the City Office for Agriculture and Forestry mentioned that plans for urban gardens existed in the 1990s and 2000s, but more detailed and documented information was unavailable.

"Wild" gardens have become urban "loose spaces". This term, coined by Karen Franck and Quentin Stevens, denotes an urban site for which people "recognize the possibilities inherent in it, and make use of those possibilities for their own ends, facing the potential risks of doing so" (Franck and Stevens 2007: 2; Gulin Zrnić 2015: 53). One gardener said that it was a "plain meadow" with "soil that had rested for years" - a recognition of the inherent potential of the site - where she began to grow vegetables. Municipal authorities have tolerated "wild" gardens; after all, it was the gardeners who took care of the vacant plots and maintained them until the municipal government decided to use them for further construction. The provisional state of these "wild" gardens (potential risk) could last for 30 or 40 years.

"Wild" gardens consist of numerous gardeners who have individually appropriated parts of vacant land, cleaned it, and prepared it for growing food. Beside vegetables, herbs and flowers, they usually plant trees (mostly fruit trees and walnuts). In spite of the transient character of the "wild" gardens' status, trees were signs of continuation and persistence. Small huts, tables, and benches were constructed within individual garden plots. Gardeners fence their gardens with decorative bushes or waste materials (such as bed slats, clothes dryer stands, metal frames, or plastic blinds). Improvised doors secured the entrances to these garden plots, and some of them were locked with similarly improvised (wooden or

${ }^{6}$ Mirjana Popović graduated with a degree in forestry from the University of Zagreb, Croatia. In the mid-1950s, she attended a postgraduate landscape design study programme at the Department of Town and Country Planning, Durham University, UK. Popović herself was quite inspired by British parks and landscape architecture. She was also acquainted with the practice of allotment gardens there, and after her return to Zagreb and work at the Zagreb Urban Planning Bureau, she advocated the idea that gardens should be incorporated into Zagreb's spatial planning as a particular type of green public space. 
metal) contraptions or even padlocks. The fencing clearly indicated a feeling of "private property", regardless of their illegal status. Moreover, it signalled the intent to remain isolated, rather than to be incorporated into the gardening community - which is the aim of new, recent garden initiatives. However, some gardeners jointly invested money into water pumps (for several gardens at the location), indicating that specific issues were recognised as collective. However, they did not develop any type of formal organization or cooperative.

"Wild" gardens exist even today, although they are fading due to the new financial powers investing in the city. They are generally cultivated by an older generation of local residents. All of them explained their motivations for gardening in contrasting arguments, such as of being in nature vs. flats, socialising vs. alienation, beautification of space vs. dereliction; many gardeners also discussed economic reasons for growing food in the city, while others mentioned recreation and fun (Gulin Zrnić 2009: 130-132, 2015: 55; Stojan and Čaldarović 2006; Biti and Blagaić Bergman 2014; Slavuj Borčić et al. 2015). Gardeners were mostly seen as "people with rural origins" or "peasants in the city" (Gulin Zrnić 2009: 131). However, long-term research sheds light on a significant discursive shift towards the view of gardening in ecological and sustainable communitarian terms.

Since the turn of the millennium, much of the neglected land has been turned into construction sites, and "wild" gardens abruptly dwindled. The loss of "wild" gardens was not questioned in public, since it was not regarded as an issue in the new post-socialist city, which was guided by deregulation in planning, private investment, and a consumerist lifestyle. However, architect and sociologist Fedor Kritovac voiced a rare opinion on urban gardening, stating in the Municipal Newsletter (Komunalni vjesnik) in 2002 that "planning, communal, and ecological interest in Zagreb gardens is not evident". The author proposed that some current ("wild") garden lots might be maintained in the urban landscape and "could be combined or incorporated congruently into the newly planned parks of Zagreb" (Kritovac 2002; cf. Gulin Zrnić 2015). This is the comment showing a different discourse on urban gardening within the politics of public space, contextualizing it as a European gardening practice and considering gardens part of the urban fabric. The comment anticipated issues that have become current ten years later.

\section{GARDENS IN THE NEW CONTEXT: THE RE-SEMANTISATION OF TRANSITION}

The last decade has brought "small" civic initiatives, direct action, and self-organizing to the fore as means to enact social and political changes. This has been a reaction to the hierarchical manner of state and local governance, as well as to global crisis. Gradually, critical and semantically different relationships towards consumerist lifestyles and neoliberal markets have emerged in Croatia. The discourse of sustainable development has become more prominent. Some concepts and terms like "shared", "public", or "communal" - which were previously burdened with socialist ideological inputs and neglected in the 1990 s - have been reaffirmed. The reassembly of meanings has been in progress. 
In this context, urban gardening appeared as an issue in 2012, when "wild" gardens in the Travno housing estate were destroyed following a decision of the municipal authorities. A newly formed civic initiative, together with existing branches of green activist groups, began to advocate urban gardening as a necessary strategy for sustainable urban development. The initiative was a reaction to the current local situation, but was also correlated with various practical European urban initiatives aimed at changing established consumerist consciousness and life habits. These initiatives, for instance, organise skill-sharing, community-supported agriculture groups, permaculture courses, seed distribution, local currency, time banks, and "do-it-yourself" (DIY) workshops. This kind of approach is at the core of the global Transition Movement, a reaction to the global ecological crisis, particularly a reaction of local communities to climate change and shrinking supplies of cheap energy.? In Croatia, the "transition network" is focused on "advocating social change in accordance with resilient and strong local communities with a minimal ecological footprint" (Dragičević and Maljković 2013) and promotes, assists, and initiates various ad-hoc initiatives, events, workshops and training sessions in collaboration with local communities and related civil organisations. ${ }^{8}$

The notion of "transition" thus requires a radical re-semantisation, especially in the context of Croatia and other post-socialist states. Previously, in the 1990s, it referred to a fundamental change in the political, economic, and social system, while nowadays it refers to a fundamental change in consciousness and practices; previously, the transition was run from above (the government), while it now connotes engagement from below (active citizens). Moreover, the previous notion of transition implied that changes are inevitable and that citizens were only transition-bearers. The new notion of transition is proactive, requires initiative, is constructive, and citizens are transition-builders. ${ }^{9}$

The following part of the article describes and analyses the actors, structures, and relationship dynamics in three urban gardens in Zagreb. The terms that denote various types of garden(er)s are based on the words of the gardeners themselves. In this paper they are used as a heuristic vessel.

\section{NEW GARDENS IN A CITY-RUN PROJECT}

In April 2012, in just a few days, the "wild" gardens of the Travno housing estate were "cleared" with bulldozers. ${ }^{10}$ The elimination of the gardens was explained as the first step towards designing a public park on that particular location, thus urging for public and

7 Transition Network, http://www.transitionnettwork.org (accessed April 2018).

${ }^{8}$ See, e.g. Croatian Permaculture Association, http://www.permakultura.hr/ (accessed April 2018).

${ }^{9}$ This is a reference to and paraphrasing of the idea of "culture-builders" developed by Frykman and Löfgren (1987).

${ }^{10}$ Cf. media report, Balija (2012). 
collective vs. individual (gardeners) use of the space. Indeed, the park was planned and envisaged by the current Master Plan as well as by previous Master Plans from 1971 onwards. This situation provoked the inception of the civic initiative Parkticipacija (park + (par)ticipation). The nucleus of the initiative consisted of 15 people in their thirties from all over the city, who were highly educated and already involved in various alternative associations (Pravo na grad, Zelena akcija). The initiative was a reaction to the abrupt removal of the "wild" gardens without almost any notification of and explanation to the gardeners and other residents in the neighbourhood. They criticized the municipal government for destroying of gardens and stressed the importance of growing food in the city. They also criticized city authorities for governing public spaces exclusively from "above". During the spring of 2012, Parkticipacija began a public campaign to establish community gardens as newly organized public spaces, and for the new - participative and active - role of citizens. It organized the signing of a petition for the first community garden in Zagreb and developed the idea of community gardens into a constructive and applicable project with recommended locations (vacant lots owned by the municipality). ${ }^{11}$

After ignoring the requests, actions, and proposals for the community gardens for almost a year, city authorities finally responded. In early 2013, the City Strategic Planning and Development Office presented potential sites for "public city gardens".12 In the spring of 2013, just as the election campaign for mayor had begun, the mayor of the time, Milan Bandić, presented the "City Gardens" project (Gradski vrtovi). ${ }^{13}$ The project has been focused on "organising and equipping arable land in municipal ownership and giving it to the citizens of the city of Zagreb to use to produce food (vegetables and berries), herbs, and flowers for their own needs" (Gradski vrtovi project). To be granted a garden plot, one must be a resident of the city of Zagreb who does not own arable land in Croatia - preference is given to citizens with lower income, large families, war veterans, or pensioners. The contract is for two years without charge, with the possibility of extension after the initial term. Individual garden plots are 50 square meters in surface area (ibid.). From three locations in spring 2013, "City Gardens" spread to 12 locations in 2017 with more than 2,000 garden plots across over 20 hectares at present (ibid.). Each garden location has a common use area with composters and recycle bins, pre-fabricated structures for tools, plastic reservoirs for water, wooden huts, and benches. Another, consecutive project

${ }^{11}$ The Parkticipacija initiative and arguments for community gardens, as well as an on-site performance on prospective location in 2012 had been covered by several media reports: Šimpraga (2012); M.K. (2012); bm/VLM (2012).

12 Studija mogućih lokacija za uređenje javnih gradskih vrtova na području Grada Zagreba (Report on potential locations for organizing public City gardens in the City of Zagreb"), 2013. A few municipal offices have been included in the organisation of city-run gardens: the City Office for Agriculture and Forestry, who are in charge of the entire project; the City Office for Legal and Property Relations and City Assets; the City Cadastre and Geodetic Activities Office, which regulates the formal ability to realise the project; the City Office for Local Self-Administration; and the City Strategic Planning and Development Office, which supervises the project in terms of its compliance with spatial planning.

${ }^{13}$ On 4 April 2013, the Decision on the Implementation of the "City Gardens" Project was implemented ("Zaključak o provođenju projekta “Gradski vrtovi”, Službeni glasnik Grada Zagreba no. 9/13, 25/13). 
- "Urban Gardens" (Urbani vrtovi) - was organized by the Municipal Office and media and other sponsors who donated additional gardening tools, barbecue equipment, etc. ${ }^{14}$ The City Office for Agriculture and Forestry issued the "Gardener's Manual" (Vrtlarski priručnik) aimed at educating gardeners on soil preparation, organic cultivation, and seasonal planting. The project was wrapped in discourse on the "sustainable use of arable urban land" and raising the quality of urban life in an economic, ecological, and social perspective, and in "developing a partnership between the city of Zagreb and its citizens" (Gradski vrtovi project).

The implementation of the city-run garden project grew out of a civic gardening initiative. However, it followed a different conceptual framework than proposed by the initiative. Many ecological, social, and sustainable elements of the civic initiative idea were annulled and ignored. For instance, the idea of shared responsibility and self-organization was transformed into a hierarchical, top-down project strictly administered by the municipal government. ${ }^{15}$

However, the interest in city gardens was huge, and many citizens became gardeners. In talking with gardeners, the difference between old gardeners and new gardeners became evident (cf. also Slavuj Borčić et al. 2015). Generally, old gardeners built their garden plots all alone, while new gardeners had their gardens (soil, tools, plastic water tanks, additional equipment, chemical toilets, etc.) prepared by the municipality. In contrast to the "wild" gardens, which were fenced with recycled materials, some of the new gardeners fence their individual plots within the garden location and build fences out of bought and ready-made materials. The interviews also reveal generational differences: "wild" gardeners are people of older age, whereas new gardeners are generationally a mixed group including more children, who accompany their parents. ${ }^{16}$ Old gardeners grew food in various ways, but new gardeners are contractually obliged to grow organic food. Furthermore, old gardeners did not develop their gardening practice in conjunction with the ideas of sustainability and community. These concepts are discursively prominent today, particularly within the framework of the community gardens, and modestly so within city-run gardens. The new gardeners create some forms of networking and community, particularly among younger people, although there have also been comments about gardeners who do not even so much as greet other gardeners.

Urban gardening is a process on every level from the ground to the administration. It has its own dynamics, formalizing phase, and contested issues. New gardeners sometimes react to problems in infrastructure and inadequate design. According to the municipal officials interviewed, they strive to work on solving problems and discuss proposals that

14 “Urban Gardens” Project, as part of "City Gardens” Project, is focused on sponsorships and donations.

${ }^{15}$ The discrepancy between the project proposed by the Parkticipacija initiative and the one that was implemented by the City government was discussed extensively in correspondence within the Parkticipacija e-mail list (2012-2013) and criticised in the media (Šimpraga 2013a, 2013b, 2013c).

${ }^{16}$ Generational differences are also recognized in Slavuj Borčić et al. (2015). 
come from the gardeners themselves. For instance, one debated issue is that of the plastic water tanks, which were occasionally filled with water by the municipality. Neither this system of providing water for vegetables nor the distribution of water tanks on the site were successful. The solution that Parkticipacija initially proposed - water pumps that could be easily installed at the garden site due to underground water - was initially ignored by the municipality, and was introduced only in the later phase as more convenient and sustainable solution.

Municipal officers occasionally perform field work and try to adapt the "City Gardens" model (in governing and outfitting) to the particular circumstances at each garden site. In a "top-down" model of management as was implemented in Zagreb, the garden thus becomes "an experiment" (Dobrić 2015), not only for the gardeners, but for municipal employees as well.

\section{ALTERNATIVE CITY GARDENS}

In the spring of 2013, a few citizens at the Prečko housing estate invited their neighbours to support the establishment of gardens on a nearby abandoned plot. A group cleared the ground (a truckload of rubbish), ordered the ploughing of the soil, and began to grow food. Simultaneously, they made efforts to administratively and formally arrange the use of this particular vacant municipal plot for urban gardening. Since this gardening group does not fit into the municipal gardening form, they succeeded in negotiating with the municipality for informal approval, but still garden without legal permission. By the end of the year, the EkoEkipa Prečko civil initiative had 70 gardeners. The group was generationally mixed, and many of its members were connected through personal relations and social networks within the neighbourhood. Some people also joined them from adjacent neighbourhoods. The garden was built by the local community, and it has simultaneously helped to strengthen the local community. The empowerment of the community arose through learning and sharing gardening knowledge and skills, "learning tolerance, differences, and acceptance" (from an interview in Radovanović 2015: 120) in many organizational and functional issues, cooperation, workshops, enthusiasm, and joy. Various activities have spread from the community garden group in the neighbourhood: the installation of a small street library in a recycled bookcase, cooperation with the neighbourhood primary school and the establishment of a school garden in following years, the organisation of young volunteers, workshops with children (organized in the garden), and the encouraging of various sharing gatherings (seedling-share, toy-share, book-share, etc.). ${ }^{17}$ In several TV

17 This garden community and its dynamics over two years (2013-2014) is described by an insider and in collected interviews by Radovanović 2015. A visit to Prečko in May 2018 on the occasion of "Neighbour Day" proved the vibrancy of the local community (sport games, sharing opportunities, children's activities) and the involvement of various local actors (kindergarten, primary school, local parish, various civil associations). 
and radio broadcasts, all these activities were presented as positive examples of building the community and fostering intergenerational interaction. In the words of one gardener, they designed "alternative city gardens".

In addition to the corpus of literature on urban gardening, in which only two types of gardens are analysed (Biti and Blagaić Bergman 2014) or all post-2012 garden initiatives are combined into type of "new" gardeners (Slavuj Borčić et al. 2015), the authors propose a more nuanced analysis aimed at multiple differences along various lines. The case study of Prečko points at the comparison of various types of gardeners' engagements within the city, specifically that of old, new, and alternative city gardeners. Both old gardeners (in the "wild" gardens) and alternative city gardeners applied the squatting strategy on vacant and derelict lots and used land without formal municipal permission. However, a significant difference lies in the social potential that characterizes the alternative gardeners - a straightforward initiative for self-organizing and social and civil engagement that moves beyond gardening itself. Alternative gardeners share the orientation towards ecological sustainability and organic cultivation with the new gardeners (those in the city-run garden project). Still, for new gardeners, this is an obligation arising from the contract they sign with the municipality, while it is a genuine choice for alternative city gardeners. In terms of social sustainability, there is also a difference in the type of approach. New gardeners are a group of people who are selected for gardening by the municipal authorities through an application process, and then they start to develop basic networking and social capital. Conversely, alternative city gardeners base their activities in existing social capital (personal relations, local and international social networks) that has been strengthened through joint activities in initiating the garden and other neighbourhood activities. New gardeners are given ready-made gardens, and many of the organisational problems (preparation of land, division of plots, etc.) were already solved, and therefore, self-organization is something that could potentially be developed in the future. The alternative gardeners began with self-organisation at the outset, and involvement in preparing, organising, and constructing the garden produced strong attachments towards what the gardeners perceive as "their" garden. Still, the change in gardeners over the years has brought new people who do not share the initial impulse and enthusiasm of involvement: they are simply users of already established gardens. There are also differences in terms of the management of the gardens. Old gardeners are not formally organized; new gardeners in a particular garden location in the city are encouraged to elect a representative who communicates with the municipality for various issues; alternative city gardeners would like to foster a truly democratic way of organising and consensual decision-making. However, the leadership has become debatable. In the new gardens, many gardeners do not want to take up the responsibility, and this is mostly due to the fact that the garden group is formed out of previously unconnected individuals and that the scope of responsibility and self-organisation is bounded by municipal regulations. In the alternative city gardens, the idea of sharing responsibility (for example, a different gardener each month is responsible for collective issues) and consensual decisions are not adopted by the whole group, and gardeners tend 
to perceive the initiators of the garden or those who are more engaged in garden affairs as representatives and leaders of the garden. ${ }^{18}$ Furthermore, in contrast to old gardeners who did not have a strong position to fight against the destruction of their gardens, alternative gardeners hold strong ecological and social arguments when negotiating with the municipality. New gardeners in a city-run project are of various standpoints, and some of them share the idea of radical change, but this heterogeneous group (which is also under a certain level of "control" by the municipality, the formal owner) is not genuinely characterized by activist engagement, as the alternative gardeners are. In comparison to old and new gardeners, alternative city gardeners incorporate the idea of community building, through which they implicitly react to ecological crisis, inadequate municipal governmental strategies, and crises of consciousness in order to create some new models of activity (at personal and group levels), thus constructing a new transitional reality.

\section{HYBRID GARDENS}

The fourth example of urban gardening is a reaction to the introduction of the city-run gardens, but it also shows how the local (neighbourhood) community can be empowered by the active engagement of its citizens, who are guided by their various goals that address the municipal government and its projects. In the summer of 2013, the self-organised residents in the Savica neighbourhood - the "Save our Park!" (Čuvajmo naš park!) civil initiative - began to protest against the plan to build a church within a neighbourhood park. They signed a petition against the location of the church in a park and gathered in various leisure and recreational activities on the park lawn. The protest was supported by a number of city NGOs, and it was covered by the media, which interpreted their movement as a protest for green public spaces in the city (Šimpraga 2013d).

A month later, the municipality began to clean terrain near to the park, which was partially abandoned (green, overgrown, and home to a significant number of birds), but also, for decades, the site of "wild" gardens. The Savica gardeners sounded the alarm to the gardeners in other neighbourhoods, local residents, civil organisations, and the media about the unexpected construction work and the destruction of the "wild" gardens. They thought that the lot had been allocated for the church instead of the one in the park. The gardeners became very active in demanding answers from the municipality, researching planning documentation and the legal status of the land. The local "Save our Park!" initiative in Savica cooperated with the local gardeners, and a number of garden workshops and gatherings were organised jointly to address the threat to their "wild" gardens. They also demanded that the gardens be kept at the existing location, but not according to the city-run garden model. They instead argued for the legitimacy of gardens on the basis of

${ }^{18}$ On the issue of management of gardens, power relations, leadership, and authority, see also Dobrić (2015). 
several decades of gardening practice on the same location. They also stressed that the existing gardeners wanted to design the gardens themselves, take care of the infrastructure and organization, make decisions, and introduce education programmes.

In the end, the gardeners remained there, and the church building was not built in the park. The "wild" garden location with its old gardeners was incorporated into the "City Garden" project with new gardeners on the surrounding land. Roughly 15 self-organised old gardeners, aided by civil organisations and media pressure, presented themselves as active participants in disputes with the municipal government over the gardens and green areas. They now strive to build a strong local community out of a generationally and socially mixed group of people, connected mostly by their interest in gardening.

Still, the local community of gardeners is not immune to controversies or disputes. For example, the problematic "top-down" model of managing the city-run gardens is present, located and visible on one exclusive plot (the largest one) within this garden - the one that has been allocated by the City Office to mayor Milan Bandic himself, and is maintained by city-run services and employees. The notion of exclusivity and privatisation of public space, the perception that gardeners are excluded from the decision-making process and that the gardens actually serve the mayor's campaign, are heavily condemned by the gardeners, as they made clear in their interviews. It is not rare to hear gardeners bitterly calling both city-run gardens and the hybrid gardens "Bandićs gardens" (Bandićevi vrtovi). Another example of internal controversies and social dynamics relate to generational and gender segregation within the garden. Both young and elderly female gardeners point out occasional feelings of inferiority, exclusion and disadvantage in certain common areas of the garden in which usually only men of the older and middle generation gather, talk loudly and share inappropriate comments towards women. Internal disputes can also be detected between gardeners who enter the garden with a dog, and those gardeners who do not share the same sentiments towards pets (in the garden). Media and television could be a matter of dispute as well. Though possibly for pragmatic reasons, the media tend to address the same gardeners to report the garden news, causing the anger of gardeners whose garden is not part of the broadcast. Security of the gardens, imposed by the municipality (security guard present $24 / 7$ ), is also a matter of dispute in the garden addressed by gardeners, as the notions of how the gardens are used as public space (for example at night) differ between city actors and the gardeners themselves. Additionally, the feeling of constant surveillance creates a sense of tension and discomfort in many gardeners rather than security.

The comparison of old, new, and alternative city gardens illustrates that the Savica gardeners form a kind of a hybrid garden who incorporate and modify various practices and discourses. New gardeners are organized by the municipality, alternative city gardeners act outside of the municipal model, while the Savica gardeners resisted the municipal gardening model. The Savica gardeners are old gardeners who adopted new discourses and benefitted from the pre-existing gardening social network, other pre-existing local 
self-organised initiatives, and the established position of the civil green associations and initiatives, which have all grown stronger in recent years.

Maintenance of the "wild" gardens and, consequently, their "defence" against the advances of the municipality, present the success of old gardeners and even represent a benchmark of how to oppose the still top-down manner of governing the city. However, this can also be seen as a kind of deconstruction of this hierarchical relationship and the appearance of some new possibilities for negotiating and decision making, which could be based in a more participative approach.

\section{THREE FACETS OF GARDENS: COMMUNITY, GOVERNANCE, AND SUSTAINABILITY}

In the 1980s, ethnologist Dunja Rihtman-Auguštin characterised "wild" gardens in the newly built Zagreb housing estates as an example of "alternative urbanisation". The use of space in estates was totally planned, and Rihtman-Auguštin valued new practices like gardening as a deviation from abstract and normative urbanisation, as a spontaneous, undisciplined, and creative intervention into urban space. Furthermore, she considered these interventions to have the potential to create an estate's community and a sense of belonging (Rihtman-Auguštin 1988: 96-101). However, the general vision of the modern (socialist) city in the second half of the $20^{\text {th }}$ century did not include agriculture - and the "wild" gardens were perceived as anomalous in the urban fabric. Recent reviews and re-evaluations of gardening practices in the world throughout the $19^{\text {th }}$ and $20^{\text {th }}$ centuries have reaffirmed them as "informal urbanization" and "an important dimension in the development of the city from the bottom up", thus valuing gardening as "the radical strategy of hands-on urbanism" (Krasny 2012: 11).

The analysis of Zagreb's gardens illuminates three concomitant dimensions - community, governance, and sustainability - and how they work together in the local context. The three dimensions are actually urban processes of building (community), shaping (governance), and living (sustainability) with various intensities and interactions. The remainder of this discussion shall suggest a few more analytical comments and address the importance of urban gardening practices and initiatives in city-making. The concept of city-making refers to comprehending various actors, factors, and processes that shape and transform contemporary cities. ${ }^{19}$

In these particular ethnographic cases, community building illustrates a different dynamics of social networking and social capital. In other words, the gardens could be "a consequence or a source of social capital" (Firth et al. 2011: 564), which might lead to two different categories of communities - "place-based" and "interest-based" (Firth et al. 2011).

19 "City-making: space, culture, and society" project, see: www.citymaking.eu. 
The Prečko (alternative) and Savica (hybrid) gardens are "place-based" communities; they are internally driven, initiated, and guided by local residents whose social networking is not only focused on the gardens, but also on other local developmental affairs. The new gardens are "interest-based" communities - they are initiated by the municipality and the gardeners gathered there through an application process. Indeed, the new gardens are an opportunity to develop and/or enhance social capital, which could be of further benefit to local communities in the area. However, the communities reveal themselves as contested spaces internally (such as disputes over the use of common space or the interdiction of pets) and externally (management and relationships with the municipality over governing urban spaces). This particular research shows that gardens are heterogeneous communities and spaces; they should be understood as "plural, complex, and tension-filled cultural spaces", specifically when some new perspectives are opened, for example by feminist or political ecology frameworks (L'Annunziata 2010). One of the problems that gardeners face is the transient character of the gardens. The plots of "wild" gardeners and alternative city gardeners are under the threat of being destroyed and jeopardized by new urban investors. This is a type of "exposure" that the gardeners constantly face (Biti and Blagaic Bergman 2014). In other words, "urban land values being comparatively high, agriculture will always compete with other uses" (Katkin 2012). Even the new gardeners in the city-run garden are exposed, although they have signed a two-year contract. An official municipal document from 2013 defines that "gardens are a positive example of the sustainable use of municipal land until its realisation according to spatial/urban plans". ${ }^{20}$ Another tacit sign of the provisional character of the gardens in the city-run project is a ban on planting trees on garden sites. Trees would be a sign of continuity of practice, as well as of the long-term commitment of the municipality to gardening as an urban community building strategy.

The issue of governance includes two basic types of top-down and bottom-up initiatives - establishing and managing the garden. These four ethnographic examples show various and even hybrid approaches in Zagreb. Some authors argue that community garden projects can be an important way "for a municipal government to engage citizens in addressing the social problems in their neighbourhood" (Henderson and Hartsfield 2009: 13) and that, through garden activities, people "produced themselves as aware, involved and indismissible urbanites" (Eizenberg 2012). This kind of approach is clearly demonstrated in the example of the alternative city gardens. However, although Western cities increased participation of their citizens in urban affairs - which is interpreted as "the democratisation of urban governmentability" - the same steps might work "as a mechanism for the further neoliberalization of cities and as a means to suppress possible resistance from below" (Eizenberg 2012: 106). This could be especially valid in terms of Zagreb's city-run gardens, which were introduced and managed as top-down and guarded

${ }^{20}$ Studija mogućih lokacija za uređenje javnih gradskih vrtova na području Grada Zagreba ("Report on potential locations for organizing public City gardens in the City of Zagreb"), https://drive.google.com/drive/ folders/OBw9AQFwBDnlrR3d60GU3Uy1OMms, 2013, public presentation in ZgForum, p. 3. 
locations governed and allocated by the municipality rather than green public spaces where citizens can self-organise.

Finally, a note on the issue of sustainability. Many European cities, particularly those that are instructive examples of urban sustainability (e.g. Helsinki), view urban gardening as an indispensable part of their long term urban developmental strategies. ${ }^{21}$ In Zagreb, the concept of sustainable development has been primarily affirmed in the public by civil initiatives and associations (for example, Zelena akcija, ZMAG), and it has recently been included in official municipal programmes and strategies as an important discourse. Still, urban gardening is not regarded as a constitutive element to sustainability. The City of Zagreb's Development Strategy until 2020 (Razvojna strategija Grada Zagreba do 2020. godine), a document issued in August 2017 by the City Strategic Planning and Development Office, mentions urban gardens twice. First, urban gardens are mentioned very briefly alongside recycling yards and school playgrounds as a type of use for which the city analyses spatial potential; second, they are mentioned in terms of the enlargement of urban gardens, which are envisioned as result of the enhancement of quality of public spaces (Razvojna strategija 2017: 55, 161). They are not included in the section on agriculture or green infrastructure, and active and participative management of the city is not even mentioned. In short, although some changes can be seen in Zagreb (introducing a city-run urban gardening project), stronger shifts towards sustainable practices should be made. ${ }^{22}$

It is on the state and municipal governments to provide the most effective ways to develop various sustainable living practices that can serve as the basis for new forms of "environmental or ecological citizenship" (Turner 2011). In Zagreb's case, various groups of gardeners display "the potential to promote physical, ecological, socio-cultural, and economic sustainability" (Stocker and Barnett 1998, according to Turner 2011: 511), i.e. the potential to take part in urban sustainable governance. However, the municipality does not sufficiently recognise or encourage this potential..$^{23}$

Considering the politics of space - particularly the transformation of urban public spaces - and contemporary urban governance policies and strategies, urban gardening is a politically potent form of civil engagement and (sustainable) city-making, but simultaneously a highly heterogeneous one. Some types of gardens and gardeners shifted from traditional forms of urban government to alternative governance. In some cases,

${ }^{21}$ Cf. Helsinki City Plan Vision 2050, http://www.hel.fi/hel2/ksv/julkaisut/yos_2013-23_en.pdf , p. 18 (accessed August 2015).

22 Beside urban gardening, another example of orientation towards efficient sustainable growth could be the consideration and introduction of sustainable mobility within the city. However, Zagreb currently lacks sustainable mobility, as has been critically addressed by many civic associations (Sindikat biciklista, Zelena akcija) regarding underdeveloped bicycle routes and the high intensity of motor vehicle traffic (see Sindikat biciklista 2015, 2018). An instructive example of a decisive shift towards urban sustainability is Ljubljana in recent years (Poljak Istenič 2016).

${ }^{23}$ Similar comments were made regarding Warsaw's gardens (Provéa et al. 2016). 
current urban gardening initiatives challenged and reconstructed existing power relations while addressing public spaces (cf. Häikiö 2007), in some cases only partially. All of this indicates and depicts Zagreb's current complexity and the heterogeneity of the (re)making of political and cultural identities, the politics of public space, and city-making.

\section{ACKNOWLEDGEMENT}

The paper is based on research undertaken as part of the scientific project "City-making: space, culture, and identity" (2014-2018) which was funded by the Croatian Science Foundation (project No. 2350). Project website: www.citymaking.eu.

Language Editing: Ljubomir Tot and Jeremy White

\section{REFERENCES AND SOURCES}

Armstrong, Donna. 2000. "A Survey of Community Gardens in upstate New York. Implications for Health Promotion and Community Development". Health and Place 6/4: 319-327. [https://doi. org/10.1016/S1353-8292(00)00013-7]

Balija, Petra. 2012. “Ruše se vrtovi u Travnom, grad daje 500 tisuća kuna za park”. Večernji list, 5 April. Available at: https://www.vecernji.hr/zagreb/ruse-se-vrtovi-u-travnom-grad-daje-500-tisuca-kuna-za-park-394173 (accessed April 2018).

Biti, Ozren and Marina Blagaić Bergman. 2014. "Urbani vrtovi u Zagrebu. Ulaganja i izloženost, inicijative i perspective". Sociologija i prostor 53/3: 261-271.

Butorac, Marina. 2015. “Ekološko-edukativni vrt Učeničkog doma 'Podmurvice' Rijeka”. In Vrtovi našega grada. Studije i zapisi o praksama urbanog vrtlarenja. Tihana Rubić and Valentina Gulin Zrnić, eds. Zagreb: IEF, HED, Parkticipacija, 174-180. Available at: http://www.citymaking.eu/vrtovi-nasega-grada-studije-i-zapisi-o-praksama-urbanog-vrtlarenja/.

bm/VLM. 2012. "Parkticipacija traži prvi zagrebački društveni vrt". Večernji list, 14 November. Available at: https://www.vecernji.hr/zagreb/parkticipacija-trazi-prvi-zagrebacki-drustveni-vrt-475237 (accessed April 2018).

Butorac, Marina and Dražen Šimleša. 2007. "Zelena srca gradova. Važnost vrtova i perivoja u urbanim područjima”. Društvena istraživanja 16/6 (92): 1081-1101.

Dobrić, Sandra. 2015. “Odozdo-odozgo. (Društven) vrt je eksperiment”. In Vrtovi našega grada. Studije i zapisi o praksama urbanog vrtlarenja. Tihana Rubić and Valentina Gulin Zrnić, eds. Zagreb: IEF, HED, Parkticipacija, 35-47. Available at: http://www.citymaking.eu/vrtovi-nasega-grada-studije-i-zapisio-praksama-urbanog-vrtlarenja/.

Dragičević, Gordana and Nenad Maljković. 2013. Tranzicijska mreža u Hrvatskoj. Zagreb [manuscript].

Dujmović, Josip. 2016. "Terapijski vrtovi i terapijska hortikultura kao intervencija u zdravstvu". Socijalna psihijatrija 44/1: 14-21.

Eizenberg, Erfat. 2012. "The Changing Meaning of Community Space. Two Models of NGO Management of Community Gardens in New York City". International Journal of Urban and Regional Research 36/1: 106-120. [https://doi.org/10.1111/j.1468-2427.2011.01065.x] 
Franck, Karen and Quentin Stevens. 2007. Loose Space. Possibility and Diversity in Urban Life. London: Routledge.

Firth, Chris, Damian Maye and David Pearson. 2011. "Developing 'Community' in Community Gardens". Local Environment 16/6: 555-568. [https://doi.org/10.1080/13549839.2011.586025]

Frykman, Jonas and Orvar Löfgren. 1987. Culture Builders. A Historical Anthropology of Middle-class Life. New Brunswick, New Jersey, London: Rutgers University Press.

Generalni urbanistički plan Zagreba. 1971. Zagreb: Urbanistički zavod grada Zagreba.

Glasnova, Diana. 2014. Bugarski vrtlari u Hrvatskoj. Zagreb: Zajednica Bugara u Republici Hrvatskoj.

Glover, Troy. 2004. "Social Capital in the Lived Experiences of Community Gardeners". Leisure Sciences 26/2: 143-162. [https://doi.org/10.1080/01490400490432064]

Gottlieb, Robert and Anupama Joshi. 2010. Food Justice. Cambridge, MA: MIT Press.

Gradski vrtovi (City Gardens) project, official website City of Zagreb. Available at: https://www.zagreb. hr/o-projektu/84060 (accessed April 2018).

Grbić Jakopović, Jadranka. 2015. "Bugarski vrtlari. Refleksije o povijesti urbanog vrtlarenja u Hrvatskoj”. Studia ethnologica Croatica 27: 71-104.

Gulin Zrnić, Valentina. 2009. Kvartovska spika. Značenja grada i urbani lokalizmi u Novom Zagrebu. Zagreb: Institut za etnologiju i folkloristiku, Jesenski i Turk.

Gulin Zrnić, Valentina. 2015. “'Gradski mali vrtovi'. Urbane heterotopije”. In Vrtovi našega grada. Studije i zapisi o praksama urbanog vrtlarenja. Tihana Rubić and Valentina Gulin Zrnić, eds. Zagreb: IEF, HED, Parkticipacija, 52-59. Available at: http://www.citymaking.eu/vrtovi-nasega-grada-studije-i-zapisio-praksama-urbanog-vrtlarenja/.

Häikiö, Liisa. 2007. "Expertise, Representation and the Common Good. Grounds for Legitimacy in the Urban Governance Network". Urban studies 44: 2147-2162. [https://doi. org/10.1080/00420980701518982]

Henderson, Bethany Ruby and Kimberly Hartsfield, 2009. "Is Getting into the Community Garden Business a Good Way to Engage Citizens in Local Government". National Civic Review 98/4: 12-17. [https://doi.org/10.1002/ncr.271]

Jambrešić Kirin, Renata. 2015. “Tuga središćanskih vrtova”. In Vrtovi našega grada. Studije i zapisi o praksama urbanog vrtlarenja. Tihana Rubić and Valentina Gulin Zrnić, eds. Zagreb: IEF, HED, Parkticipacija, 102-114. Available at: http://www.citymaking.eu/vrtovi-nasega-grada-studije-i-zapisi-opraksama-urbanog-vrtlarenja/.

Janovski, Sven. 2015. "Hrana je sloboda”. In Vrtovi našega grada. Studije i zapisi o praksama urbanog vrtlarenja. Tihana Rubić and Valentina Gulin Zrnić, eds. Zagreb: IEF, HED, Parkticipacija, 217-223. Available at: http://www.citymaking.eu/vrtovi-nasega-grada-studije-i-zapisi-o-praksama-urbanogvrtlarenja/.

Katkin, Rebecca. 2012. "Urban Agriculture. Symbiotic Transformations of Cities and Food Systems". Spaces and Flows. An International Conference on Urban and ExtraUrban Studies 2/3: 61-69. [https://doi.org/10.18848/2154-8676/CGP/v02i03/53858]

Kingsley, Joonathan and Mardie Townsend. 2006. "Dig in' to Social Capital. Cammunity Gardens as Mechanisms for Growing Urban Social Connectedness". Urban Policy and Research. An Australian and New Zealand Guide to Urban Affairs 24/4: 525-537.

Kolar-Dimitrijević, Mira. 2014. "Značenje školskih vrtova u sjevernoj Hrvatskoj u vrijeme Austro-Ugarske Monarhije". Ekonomska i ekohistorija 10/10: 217-232.

Komazlić, Antonija. 2015. “Uzgoj hrane u gradu. Krovovi zgrada”. In Vrtovi našega grada. Studije i zapisi o praksama urbanog vrtlarenja. Tihana Rubić and Valentina Gulin Zrnić, eds. Zagreb: IEF, HED, Park- 
ticipacija, 225-234. Available at: http://www.citymaking.eu/vrtovi-nasega-grada-studije-i-zapisi-opraksama-urbanog-vrtlarenja/.

Krasny, Elke, ed. 2012 Hand-on Urbanism 1850-2012. The Right to Green. Architecturzentrum Wien: MCCM creations.

Kritovac, Fedor. 2002. "Zemaljski odsjaj izgubljenog raja”. Komunalni vjesnik 226: 18.

L'Annunziata, Elena. 2010. "Following the Plant. The Political Ecology of a Hmong Community Garden". Humbolt Journal of Social Relations 33/1: 97-134.

Maleković, Tonka and Valentina Gulin Zrnić. 2015. "Krugovi u vrtu / Nepripitomljenost”. In Vrtovi našega grada. Studije i zapisi o praksama urbanog vrtlarenja. Tihana Rubić and Valentina Gulin Zrnić, eds. Zagreb: IEF, HED, Parkticipacija, 281-293. Available at: http://www.citymaking.eu/vrtovi-nasegagrada-studije-i-zapisi-o-praksama-urbanog-vrtlarenja/.

Marjanić, Suzana. 2015. "Izvedba vrta u lokalnoj suvremenoj umjetničkoj praksi ili o tome kako umjetnosti može biti korisna". In Vrtovi našega grada. Studije i zapisi o praksama urbanog vrtlarenja. Tihana Rubić and Valentina Gulin Zrnić, eds. Zagreb: IEF, HED, Parkticipacija, 249-277. Available at: http://www.citymaking.eu/vrtovi-nasega-grada-studije-i-zapisi-o-praksama-urbanog-vrtlarenja/.

M. K. 2012. "Zagrebu treba društveni vrt + FOTOGALERIJA!". H-Alter, 14 November. Available at: http:// www.h-alter.org/vijesti/zagrebu-treba-drustveni-vrt-fotogalerija (accessed April 2018).

Nettle, Claire. 2014. Community Gardening as Social Action. Farnham: Ashgate.

Novak, Miranda. 2015. "Zelena učionica. Vrt Edukacijsko-rehabilitacijskog fakulteta - uloga vrtova u razvoju kvalitete života”. In Vrtovi našega grada. Studije i zapisi o praksama urbanog vrtlarenja. Tihana Rubić and Valentina Gulin Zrnić, eds. Zagreb: IEF, HED, Parkticipacija, 138-152. Available at: http:// www.citymaking.eu/vrtovi-nasega-grada-studije-i-zapisi-o-praksama-urbanog-vrtlarenja/.

Orlić, Olga. 2014. "Grupe solidarne razmjene. Počeci ekonomije solidarnosti u Hrvatskoj”. Etnološka tribina 44/37: 72-88.

Pavlović Lučić, Dražena. 2015. "Zagrebački društveni voćnjaci. Priča u nastajanju”. In Vrtovi našega grada. Studije i zapisi o praksama urbanog vrtlarenja. Tihana Rubić and Valentina Gulin Zrnić, eds. Zagreb: IEF, HED, Parkticipacija, 153-164. Available at: http://www.citymaking.eu/vrtovi-nasega-gradastudije-i-zapisi-o-praksama-urbanog-vrtlarenja/.

Poljak Istenič, Saša. 2016. "Reviving Public Spaces through Cycling and Gardening. Ljubljana - European Grenn Capital 2016". Etnološka tribina 39: 157-175.

Prové, Charlotte, Joost Dessein and Michiel de Krom. 2016. "Taking Context into Account in Urban Agriculture Governance. Case Studies of Warsaw (Poland) and Ghent (Belgium)". Land Use Policy 56: 16-26. [https://doi.org/10.1016/j.landusepol.2016.04.025]

Radovanović, Vanja. 2015. “EkoEkipa Prečko. Dnevnik jednog vrta”. In Vrtovi našega grada. Studije i zapisi o praksama urbanog vrtlarenja. Tihana Rubić and Valentina Gulin Zrnić, eds. Zagreb: IEF, HED, Parkticipacija, 116-131. Available at: http://www.citymaking.eu/vrtovi-nasega-grada-studije-i-zapisio-praksama-urbanog-vrtlarenja/.

Razvojna strategija Grada Zagreba do 2020. godine. Zagreb: Gradski ured za strategijsko planiranje i razvoj Grada, 2017. Available at: https://www.zagreb.hr/UserDocsImages/gu\%20za\%20strategijsko\%20planiranje/Razvojna\%20strategija\%20Grada\%20Zagreba_SGGZ_18-17.pdf (accessed April 2018).

Rihtman-Auguštin, Dunja. 1988. Etnologija naše svakodnevice. Zagreb: Školska knjiga.

Rubić, Tihana and Valentina Gulin Zrnić, eds. 2015. Vrtovi našega grada. Studije i zapisi o praksama urbanog vrtlarenja. Zagreb: IEF, HED, Parkticipacija (e-book; printed in 2016). Available at: http://www. citymaking.eu/vrtovi-nasega-grada-studije-i-zapisi-o-praksama-urbanog-vrtlarenja/. 
Rubić, Tihana and Saša Šimpraga, eds. 2012. "Urbano vrtlarenje" (temat). Zarez - Dvotjednik za kulturu i društvena zbivanja 345: 19-28, 7 November. Available at: http://www.zarez.hr/system/issue/ pdf/471/345.pdf (accessed April 2018).

Sindikat biciklista's web site. 2015. "Biciklom kroz grad”, 13 January. Available at: http://sindikatbiciklista. hr/biciklom-kroz-grad/ (accessed April 2018).

Sindikat biciklista's web site. 2018. “Koliko Grad Zagreb ulaže u biciklistički promet?”, 21 February. Available at: http://sindikatbiciklista.hr/koliko-grad-zagreb-ulaze-u-biciklisticki-promet/ (accessed April 2018).

Slavuj Borčić, Lana, Marin Cvitanović and Aleksandar Lukić. 2015. "Zeleni prostori, voljeni prostori. Stari i novi zagrebački vrtovi u očima vrtlara". In Vrtovi našega grada. Studije i zapisi o praksama urbanog vrtlarenja. Tihana Rubić and Valentina Gulin Zrnić, eds. Zagreb: IEF, HED, Parkticipacija, 60-77. Available at: http://www.citymaking.eu/vrtovi-nasega-grada-studije-i-zapisi-o-praksama-urbanogvrtlarenja/.

Stojan, Mara and Ognjen Čaldarović. 2006. "Planiranje, spontanost i okolica. Primjer pothodnika u naseljima Trnsko - Trokut u Zagrebu". Društvena istraživanja 15/4-5 (84-85): 819-844.

Studija mogućih lokacija za uređenje javnih gradskih vrtova na području Grada Zagreba. Available at: https://drive.google.com/drive/folders/OBw9AQFwBDnlrR3d6OGU3Uy1OMms; https://www.zagreb.hr/UserDocslmages/arhiva/WEB_javni_gradski_vrtovi.pdf (accessed April 2012).

Šimpraga, Saša. 2012. "Društveni vrt na čekanju”. H-Alter, 29 June. Available at: http://www.h-alter.org/ vijesti/drustveni-vrt-na-cekanju (accessed April 2018).

Šimpraga, Saša. 2013a. "Prema prvom zagrebačkom društvenom vrtu”. H-Alter, 11 February. Available at: http://www.h-alter.org/vijesti/prema-prvom-zagrebackom-drustvenom-vrtu (accessed April 2018).

Šimpraga, Saša. 2013b. “Trt-mrt, vrt ili smrt!". H-Alter, 18 April. Available at: http://www.h-alter.org/vijesti/trt-mrt-vrt-ili-smrt (accessed April 2018).

Šimpraga, Saša. 2013c. "Između gradskog i društvenog vrta”. H-Alter, 29 July. Available at: http://www.halter.org/vijesti/izmedju-gradskog-i-drustvenog-vrta (accessed April 2018).

Šimpraga, Saša. 2013d. "Savica je novo Travno". H-Alter, 6 April. Available at: http://www.h-alter.org/ vijesti/savica-je-novo-travno (accessed April 2018).

Toš, Igor. 2015. "Urbano vrtlarstvo i participacija kao strategija”. In Vrtovi našega grada. Studije i zapisi o praksama urbanog vrtlarenja. Tihana Rubić and Valentina Gulin Zrnić, eds. Zagreb: IEF, HED, Parkticipacija, 20-25. Available at: http://www.citymaking.eu/vrtovi-nasega-grada-studije-i-zapisi-opraksama-urbanog-vrtlarenja/.

Trajkov, Zrnka. 2015. “Trnoslav. Školski i društveni vrt u središtu Zagreba”. In Vrtovi našega grada. Studije i zapisi o praksama urbanog vrtlarenja. Tihana Rubić and Valentina Gulin Zrnić, eds. Zagreb: IEF, HED, Parkticipacija, 132-136. Available at: http://www.citymaking.eu/vrtovi-nasega-grada-studije-izapisi-o-praksama-urbanog-vrtlarenja/

Turner, Bethaney. 2011. "Embodied Connections. Sustainability, Food Systems and Community Gardens". Local Environment 16/6: 509-522. [https://doi.org/10.1080/13549839.2011.569537]

Urbani vrtovi (Urban gardens) project, official website of the City of Zagreb. Available at: https://www. zagreb.hr/urbani-vrtovi/88387 (accessed April 2018).

Ursić, Sara; Rašeljka Krnić and Anka Mišetić. 2018. "Urbani vrtovi. Privremeni urbanizam i koncept privremenog urbanog vrta". Sociologija i prostor 56/1 (210): 53-69.

Vrtlarski priručnik (Gardener's Manual), "City Gardens” project, Zagreb, City Office for Agriculture and Forestry. Available at: https://www.zagreb.hr/UserDocslmages/arhiva/gradski\%20vrtovi/Gradski_ vrtovi_prirucnik_za_WEB.pdf (accessed April 2018). 


\section{STVARANJE GRADA KROZ URBANO VRTLARENJE:} JAVNI PROSTOR I CIVILNI ANGAŽMAN U ZAGREBU

Rad donosi četiri primjera vrtlarskih praksi u Zagrebu, s fokusom na njihove aktere, strukturu i ciljeve $u$ okviru raznih tipova vrtova. $U$ radu se predstavljaju prakse i percepcije bespravnih ("divljih") vrtova koji su desetljećima postojali u tkivu grada. Potom se opisuje i analizira promjena konteksta urbanog vrtlarenja u posljednjih nekoliko godina. Ocrtavaju se i obrazlažu etnografski primjeri novih, alternativnih i hibridnih vrtova, s ukazivanjem na raznolikost načina organiziranja te uključenih aktera, oblika zajedništva i solidarnosti, kao i pregovaranja te rasprava o diskurzivnim, strukturalnim i upravljačkim pitanjima. Radom se nastoji propitati heterogenost vrtlarskih zajednica i osvijetliti dinamika (razvoj i modifikacije) različitih odnosa unutar vrtova. U zaključnom dijelu rada razmatraju se politike prostora, transformacije urbanih javnih prostora i potencijali vrtlarskih inicijativa u sferi suvremene politike i strategija upravljanja gradom.

Ključne riječi: urbano vrtlarenje, tranzicijski pokret, politike javnih prostora, izgradnja zajednice, postsocijalistički grad, Zagreb 